Historic, archived document

Do not assume content reflects current scientific knowledge, policies, or practices. 
Number 2.] -COMMENCED IN 1852.- [26th Edition.

Western Trees for Western Planters.

$$
\text { WHOR.ESALE }
$$

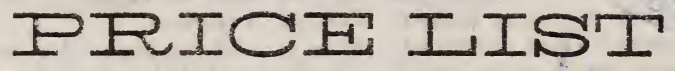

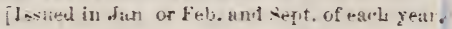

-OE TIR-
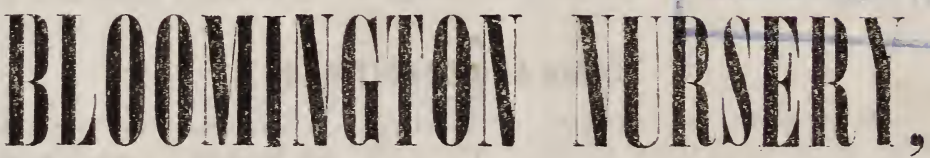

(Hrincipal office, 3.1 mile Torth-eas of the fourt House, and 1 mile Sunth ut Tormal sation.)

[Paoking and Nursory Grounds at Normal.]

BLOOMINGTON, MCLEAN COUNTY, ILLINOIS,

\section{SPRING OF 18\%2,}

After which these Rates acill not be binding.

F. K. PHCENIX, Proprietor.

BLOOHINGTON, ILL.:

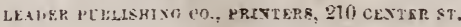

1872. 


\section{TO OUR FRIENDS AND PATRONS.}

Wrrm best thanks for past favors, we offer this list for the coming season, AT LOW CASH PRICES :

With thirty ycars experience in the business, here and at Delavan, Wisconsin, the Propriet or claims some knowledge of the varieties and modes of treatment BEST IDAPTED TO OCR PECLLIAR SOIK AND CLIHATE. Our facilities here for frompt forwarding by Railroad or Express, to all sections, are not excelled. We are but two days from Cairo, Dunleith, Cincinnati and Louisville, and but one from Chicago, St. Lonis and Indianapolis, without transfer, by daily freight trains. Those familiar with the perishable character of trees and plants, the delay, exposure and expense incident to lots brought from the East-escecially in our springs, usually so mueh earlier than theirs, will need no recommend of ours to induce them to buy West. If Western planters ever want or expect good, cheap trees, they will eertainly patronize home ar Western Nurseries.

Our Establishment now covers 600 acres, located on high, dry, lolling prairie, perfectly exposed on all sides, and no manure used for most of "our trees, giving them a thoroughly ripe, acclimated growth. We believe our stock throughout the largest and cheapest ever offered Hest. Particular attention desired to the stock of Apple, we believe unequaled for quantity, quality, variety, reliability and hardihood. Of Pear Trees and Stocks, also, we have now nearly 50 acres of both Dwarf and Standard, largely Standard. He offer over 350,000 Pear trees of, as we believe, asequaled rigror, beutity, eorreetuess and cheapness. Our Grape Vines here corer at least $: 0$ acres.

\section{TERHS AND COADITHONS.}

1.- Thus CAsin, Ner to us here, with order, or (where oriery are from known parties, or through Express 1 gents, and for points not too distant), on delivery by lixpress with return cliarges added. Our LOW prices, and the utter impossibility fer yealizing on time sales, must viudicate our terms. As far as orders cannot be filled, the money will be returned. Parties who wish goods by railroad, to be paid for on delivery, and thus save express charges, may leposit amount of bill and return charges with the express agent, to be sent to me when goods arrive and send me with their order, the express agent's receipt for the amount so deposited. Order's for distant points must encluse the cash.

2.-Stock and pacising guaranted gool. The utmost care taken to have articles true to name, and in no casc clo we wish to sell cxcept we can please customers. He desire to hear from every purehascr, and every lot scht out, not only this but precious seasons as wcll.

3.-Articles furnished at prices uamer only when the number specified is taken,

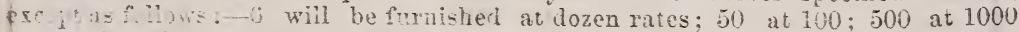
rates, when the order amounts to 5,50 or more.

lintes by the dozen, $100 \mathrm{nr} 1000$ will not apply where two or more articles or classes offered separately, are included to make np the required number.

4.-On atl if holesale Bills, the choice of varieties must be left to us. Particular varieties ramed in order, furnished as far as practicable. Orlers forbidding subatiution we fill as far oniy as we can supnly the sorts specitied.

$\therefore$ - Packing earefully cione, in hoxes mostly, sometimes bales or parcels, for which a moderate cbarge : for large boxes 8 or 9 feet $x 2 !$, sit each; smaller boxes in proportion. This includes cost of packing and delivering at Railroad. Express or Postoftice here. To pareel by mail for less than $\$ 1$. After packing and delirering at Depot, Express and Postofice here, the proprietor cannot be responsible for fosses by negleet or detention-in such cases claim must be made on the Forwarder.. Any mistakes of nurs promptly corrected. Trees per car load for Points on these Roals, or connecting ones, can be packed in bulk, and so save cost of boxing.

6.- Parties wishing Retail Orders assorted at the Nursery before packing, willIX ILL CASES-be expected to furnish a CORRECP Collated List; and to superintend and assist inthe work. On lots so assorted, the wages for laborers furnisherl in the assorting, from the aggregite stock in the trenches, will be charged to the Agent or Dealer. 
- - Parties who cannot come to the Nursery to assort their Retail Orders, are refuired to send Coliated List to pack from at the Nursery, and can assort their trees after receiving them. Those wishing Agencies will please apply therefor, sending luc. for terms. DEALERS wishing to contract should apply as such, early, with list of items and quantity wanted, naming anything not found on our List. Conditions, rates, etc., can then be furnished. No commission allowed on sales at these net wholesale rates.

8.-See offer to Pre-pay Express Charges on small packages on page 23.

\section{INSTRUCTIONS AND SUGGESTIONS.}

Remittances may be made by Postal Orders, or Bank Draft on New York, St. Louis of Chicago by mail, or U.S. and National currency by express pre-paid. Currency if by mail at sender's risk, though for years past generally safe. In sending by mail, have the letter Registered, taking Postmaster's receipt therefor. In sending ?ostal Orders, please send them WITH THE LETTER, and NOT in separate enve?spe as "Red Tape" at Washington directs.

Roses, Greenhouse, Bedding and all choice and tender Plants should be packed separate from trees, shrubs and bulky articles, and be sent by Mail or Express. Therefore please write orders for such plants on a separate sheet.

RPLEASE LET LS KNOW WHAT YOU WAN'T-FORM CLUBS AND BUY A1 WHOLESALE! SPECIAL IXDCCEMEXTS ON LARGE AYD EARIY ORDERS.

Parties ordering will please send EARLY, with order legible and separate from body of letter, with name of Postoffice, County and State ON THE ORDER, :tud he particular to state how they wish packages and invoices directed. Please let, if possible, all needed specifications as to age, size, style, etc., be stated sin the order, to save trouble of referring to previous correspondence in hurry of season. In Cities give Street and No., or No. of Postoffice Box on every letter.

TO AFOID MISTAKE AND LOSS.-Please never omit in an Order or Letter the following items: 1st, P.O.; $2 \mathrm{~d}, \mathrm{Co} . ; 3 \mathrm{l}$, State; 4th, Articles Wanted; giving the Age. Class or Size, exactly as offered in this List; 5th, shipping direction. Please write Numbers wanted to each Iot, in Figures, without using DiTTo Marks or Abbreriations.

Packages 4 lbs. or less, of Plants, Trees, \&c., can be sent by Mail, on pre-payment of 2 cents postage for every $4 \mathrm{oz}$., or fraction over-a privilege not lialf appreciated as ret. Of 20 wagon loads of mail packages sent by us last season, nearly every arvicle arrived in good condition.

Where Mailing will not answer, Expressing is confidently recommended on all small perishable lots, or for great distances, where there are many re-shipments. The have abundance (sereral car loads) of moss for putting up all plants.

If packages lo not reach you soon after receiving notice of shipment, write imnediately, that I may do what I can to trace and hasten them forward.

We usually commence packing in the Fall about the 1st of October, and in the Spring by the 13th of March, or sometimes the last of February. For the South or Fxpressing. we pack and ship Seeds, Cuttings, Cions, Stocks, Root-Grafts, and Greenlouse Plants. during mild weather in Winter.

Present R. R. Freight on Trees in boxes per 100 lbs. to Dubuque, (or Dunleith,) 296 miles, 69 cts.; Freeport, 139 miles, 65 cts.; Dixon, 103 miles, 63 cts.; Mendota, 75 miles 58 cts. : LaSalle, 59 miles, 45 cts. ; El Paso, 17 miles, 23 cts.; Decatur, 43 miles, 37 cts. : Pana, 76 miles, 58 cts.; Centralia. 130 miles, 65 cts. : Cairo, 248 miles, 76 cts.; Chicago, 125 miles, 50 cts.; Joliet, 88 miles, 59 cts.; Springfield, 56 miles, 40 cts. : St. Louis, 156 miles, 55 cts. ; Indianapolis, 78 cts.

One thousand Apple trees packed for shipping, ordinarily weigh-1 year, 1 to 3 feet, about $400 \mathrm{lbs}$.; 2 years, 3 to 5 feet, 800 ; 3 years, 4 to 6 feet. 1,$400 ; 4$ years, 5 to 7 or 8 feet, 2,200 lbs

PLEASE CALL AND SEE OUR STOCK 


\section{LIST OF CATALOGUES OF BLOOMINGTON NURSERY.}

1. General Deseriptive, 100 pages, Illustrated; 10 cents.

2. Wholesale Price List, for Nurserymen, Dealers and large Planters: semi-Asuual, 24 pages.

3. Flower and Vegetable Seeds, and Greenhouse, Bedding and Gnrlen Plan: combined, 112 pages, Illustrated. $10 \mathrm{c}$.

4. Bulbs and Winter-Blooming Plants, Illustrated, 40 pages. Fall.

5 . List of Colored Plates of Fruits and Elowers-j samples by math, for \$1.10.

The whole 5 Catalogues for 20 cents.

\section{APPLE TREES.}

1 to 23 feet, 1 year

2 to 4 feet, mostly 2 years..

4 to 6 feet, mostly 3 years................... 15

5 to 7 feet, selected, 3 or 4 years........... 20

Dwarf. -1 year, or light 2 and 3 years...... 15

2 or 3 years, medium size...........

2 or 3 years, strong, selected,......
E.tCIr.

(2)
100 S3 $00 \$ 1200$

$\pm 00 \quad 1500$

8003000

1000 t.j 00

7000

1206

1500

Leading sorts, from our list of over 350 varieties, Standard trees.

Summer.-Astracan Red, Benoxi, Carolina June, Dichess de Ohdixizi.

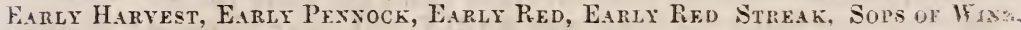
also called Williams' Favorite, or Early Washington,) SweEt Jure. with more a less Cole's Qelyce, Early Jof, Focrth of Jum, Hocking, Keswick Comin, p' mate, Sumer Pearmain, Sumpr quefx, Sheet Boggh, Trexton Earis, de.

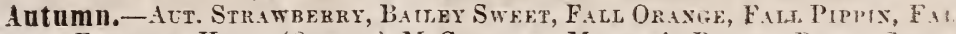

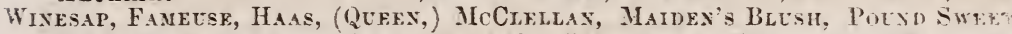
Raybo, Raysdell's Sweet, Sweet Pear, St. Lawrixce with more or less Atrty

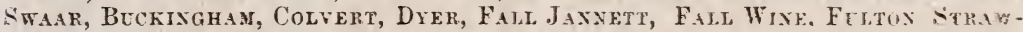

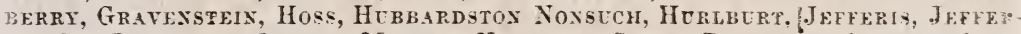
soy Co., Lowrel or Oraxge, Nother, Northeren Sweet, Purter, and many other's.

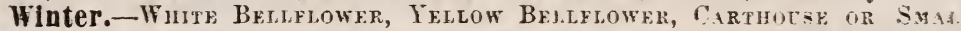

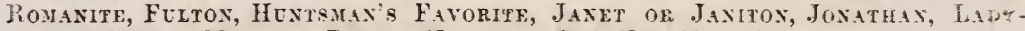
finger, Miraj, Missover Piprix, Northers Spy, New York Pippla, (Ben Datis Baltimore Red, Ren Pearmais, White Pearmas, Grimes' Goldex P'ipris. Geja.

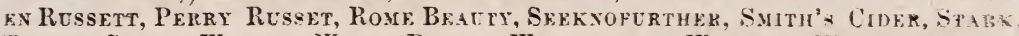

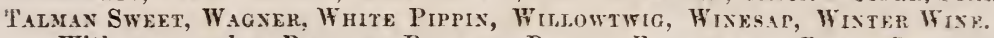

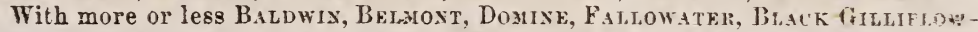

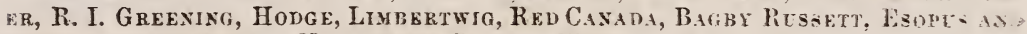
Newton Spitzenbcrg, Vandevere Pippix, Winter Sweet Parabise, and masy others. Also, over 30 varieties of Chorce Solthers Sorts, 1 and 2 yearzold. id. cluding Carter, Camack's Sweet, Cullawhee, Kentucky Streak, Oconce Cireenin: Shockley, Virginia Greening, Yellow English. Full list sent ox application.

Crabs-Hislop, Transcendent, Reu, Yellow, Purple, Foxley, Golden. 太te.

\section{Special Sorts of Apple.}

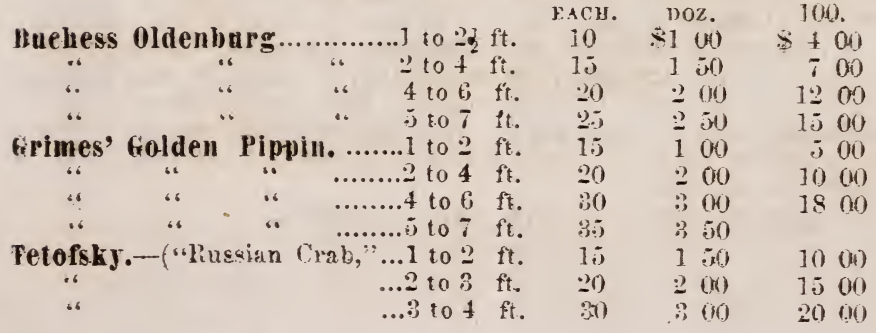




\section{Pear Trees-Most Superb Stock!}

OVER 350,000 SALEABLE TREES.

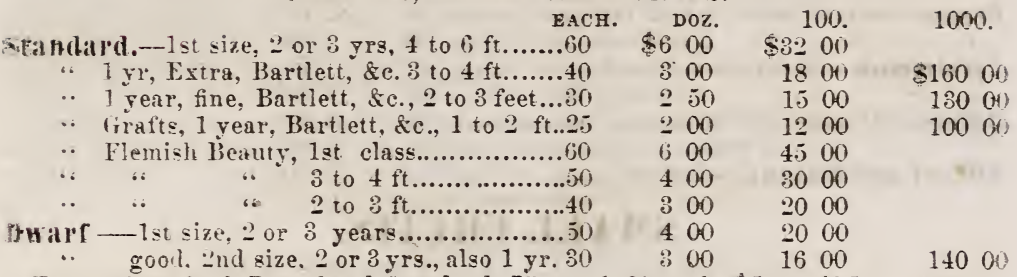

Extrat iizes, both Dwarf and Standard, 75c. to 100 each, \$.j0 to $\$ 75$ per 100 .

The tollowing are our leading sorts:

Sumner.-Ananas, Clapp's Favorite, Bartlett, mostly Standard, a large Stock 1. gear. all sizes, extra fine, B.Giffard, Brandywine, Dearborn, Kingsessing, Kirtland. frinand's Summer, Rostiezer, Trson, \&c., \&c.

Fall.-Belle sucrative, Beurre d'Anjou, Buffum, Des Nones, Doyenne Bou- sck, Duchess d Angouleme, -nd most popular Dwarf, but few Standard, Flemish l.eauty. mostly standard, Howell. L. B. De Jersey, most popular Dwarf; Onondaca or 'Swan ' Urange, Seckel, Sheldon, only Standard. Srevens' Genessee, Urbani-te, Virgalien er White Doyenne, with more or less B. Goubalt, B. d'Amanlis. Tenrre Deil, Golden Beurre, Fondant Charneuse, B. Superfin, St. Ghislain Standari unly. V. M. Leon Le Clere. Tan Assche, \&e., \&c.

Hinter.-B. Laster, Glout Morceau, Lawrence, Vicar or Le Cure, with more - bese d'Aremburg, D. Sieulle, Figue d'Alencon, Langelier, Lewis, W. Nellis, \&c. sets In all 100 ) sorts.

\section{Plum Trees.}

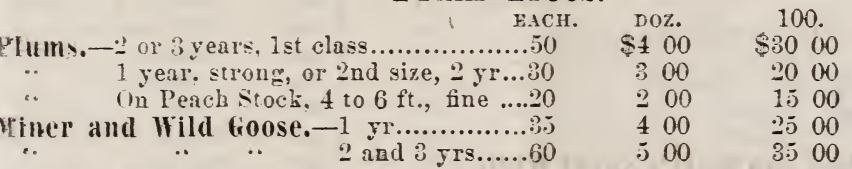

The Wild Goose is much the largest and finest very early Native Plum known - the tree very proluctive, and promises to be perfectly hardy in the North.

We have over of rarieties Plum, and good supply of Lombard, Smith's Orleans. Experial Gage, \&e.

\section{Cherry Trees.}

\begin{tabular}{|c|c|c|c|}
\hline Wach. & Doz. & 100 & 1000. \\
\hline Sarly Kichmond. -1 st class 2 or 3 yrs........ 50 & $\$ 500$ & $\$ 2500$ & \\
\hline $\begin{array}{l}\text { Mearts, Dukes.fe., medium } 2 \text { yrs.................. } 40 \\
\text { Peach Trees. }\end{array}$ & 350 & 1800 & $\$ 16000$ \\
\hline 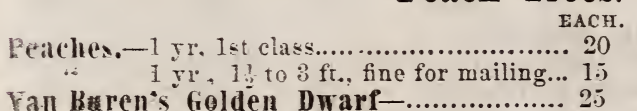 & $\begin{array}{l}\text { Doz. } \\
8200 \\
120 \\
200\end{array}$ & $\begin{array}{r}100 \\
\$ 1050 \\
600 \\
1200\end{array}$ & 1000. \\
\hline
\end{tabular}

It you wish, as many do, Peach Trees cut back to 3 feet, please say so on the order.

\section{Miscellaneous.}

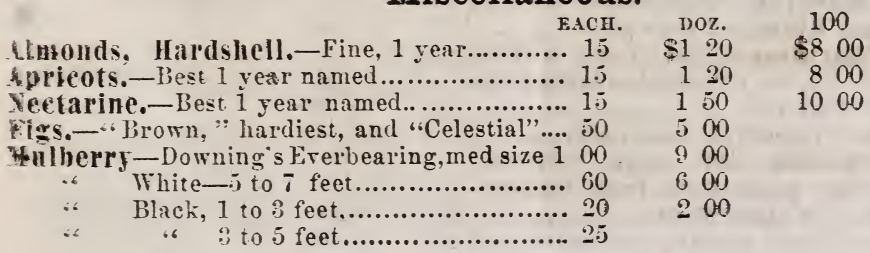

1000 


\section{MISCELYANEOUS-CONTINUED.}

Pecan-Native, hardy, 1 to 2 feet .............. 20

100. $\quad 1060$

".. $\quad 2$ to 3 feet

$\begin{array}{lll}30 & 3 & 00\end{array}$

Persimmon-Hardy, fine, 6 inch .............. 10 10

$75 \$ \$ 00$

Quince.-Orange, 2 years

" 2 to 3 feet

Filbert and Walnut.-English................... $30 \quad 300$

\section{SMALL FRUITS.}

6 for $\frac{2}{3}$ the price of $12 ; 50$ for $\frac{2}{3}$ the price of 100 .

\section{Currants.}

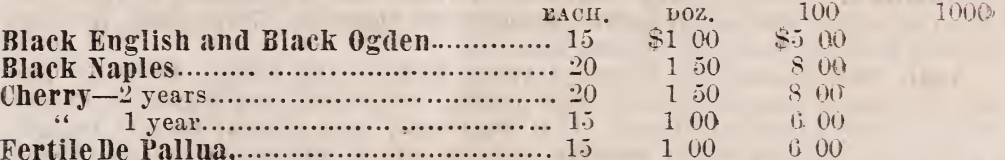

cerise de Tours, Crys. White. Fertile D.Angers, Gondoin Red, La Fertile, Le

Hative, Long Bunched Red, May's Bangup, Red Provence, Striped Fruited.

White Antwerp, White Transparent..... 1. 100

Prince Albert-............................... 20 200

Red Dutch and Extra Red-2 years .......... 15 $100 \quad \div 00$

" 1 year...............................

Victoria-(Red Grape) superb sort, 1 year... 15

$$
\text { "6 } 2 \text {.. } 2 \text { year... } 20
$$

Versailles -2 or 3 years..................... 20)

White Dutch-1 or 2 years..................... 15

White Grape -1 year.......................... 15

\section{Gooseberries.}

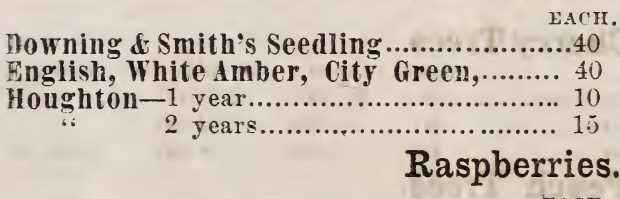

Black Miami or IcCormick-Esteemed,

\section{EACH.}

later, larger than Doolittle : tips..........

B. De Fontenay-Fine, fall bearing purple... 15

Brinckle's Orange..............................

Clarke-Superb, new, hardy, red, very large 15

Doolittle Improved-Rooted tips.

Doolittle and Yiami-2 year plants............

Davison's Thornless-(Black Cap), without thorns, early, very fruitful, worthy ; tips

Franconia-Fine red

Golden Cap-Productive, hardy sort........... $\mathrm{nOZ}$

Herstine-Splendid, new, large, delicious, 
Nammoth Cluste: Each. 1) 07. 100 1000

Ohio Everbearing. .15 $\$ 100$ 8500

150

Philadelphia-Harly, red, very productive.. 15 Seneca Black Cap and Early Andrews.... 15

100

200

Turner-Upright, almost thornless, very vigorous, productive, perfectly hardy. raise 20 years ago and recommended by Prof. Turner, Jacksonville, Ill , as best of all with him. Large, supert) red, delicious, long in berring. Price of the careras: plants, 15 cents each, 81 per dozen, sis per 100, s25 per 1000 .

\section{Blackberries.}

Ancient Hriton-Very hary and prolific,

claret most delicious tharur.

Kitatinny-Warmined true and tirst-ches...

Eawton 15

$\$ 100$

$\therefore 00$

$100 \quad 300$

2.5 100

$\because \div \quad 100$

Missompi Mammoth $-\ldots \ldots \ldots \ldots \ldots \ldots \ldots \ldots$

Hilson's Karly-Large, early, ploductive.....

50) 200

$\$ 80+3$

\& or

2.) 100

$8(0)$

\section{Strawberries.}

Three dozen is Iail for $\$ 1$, not less than 12 of one sort.

Five hundrerl by Mail for $\$ 5$, not less than 100 of one sor:.

Eqriculturist-Very large, productive...................

Baltimore scarlet......................................

Boudinot-New, highly praised ..........................

Boyden's No. 30.- Tery large and five..................... 8;

Burr's New Pire-Very early.......................... s;

Charles bowning-Large, fine, new and prodrctive.... 35

Col. Hllsworth ...........................................

Deptford White-Fine to cau...........................

Duc De Malakofi....................................

Fresch's SeedPing-Large. early, swet.................

Green Prolifíc-Large, scadet. produetire............... :

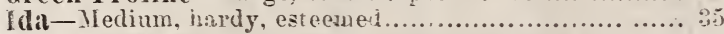

lowa or Washington-Larly, pioduetive................

Jenny Lind ..............................................

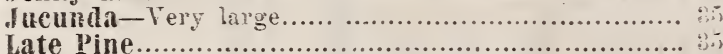

Late Pine...................................................

Mcdroy's Superior-Late, hardy ........................

Michigan-Sunerb, new, late, productire...................

Uonitor-Large, scarlet................................ is

President Wilder-New.................................. to

Kussell's Prolinte......................................... ;

Triumph de Gand-Very large, late and sweet...........

Wilson's Albany-tinormous bearer..................

? Pres. Wilder
ivo excepted.

$\$ 100$

100

100

100

100

100

100

100

100

100

100

100

100

100

100

100

100

100

100

400

100

100

100
Sto 00

600

(5) 00

800

j) 00

800

ij 0

50

$5 x^{2}$

6 ON

(6) 00

(i) 00

¿ 00

(5) 00

(i. 00

j $\mathrm{CO}$

800

5)

\section{GARDEY ROOTS AND SEED POTATOES.}

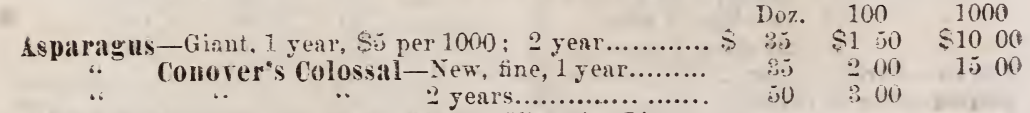

Rlubarb, Vinegar or Wine Plant-Victoria, Linne-
us, and limperor.
180
j 00

Early Rose Potatoes....Best Eariy, $7 . \ldots$ cents per peck; 82.00 per bu, package free. White Peach How-Finest keeper, i5 ets. per peck :2 pes bi., package free. 


\section{Grapes.}

Eully thirty acres of (irape Fines in cultiration here. Jearly all our plants are srown in open air from layers, eyes or cuttings ; no pot plants whaterer. A H.ARfu,

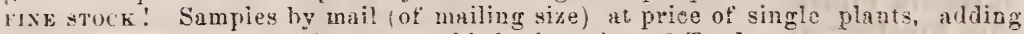
tive cents for posiage. Six for two-thirls the priec of fwelre.

Idirondac-Yery early. E.ICH. Doz.

Allen's Iybrid-1 or '2 year......................

Alvey-(see Hager.)

Anna-1 or 2 years.

$\$ 300$

Irnold's Hybrid Yo. 5 .

Blood's Black-Yery early, healthy, 1 and 2 year Ganby's August--Hyde's hliza and York Marleira...

Cassidy-White

Catherine

Catawba-1 year.

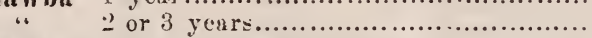

20

2500

in)

25

20

35

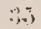

Chiristine-Telegraph, carly, hamly, black, 1 or 2 yr

$$
\text { . } 3 \text { or } 4 \text { year: }
$$

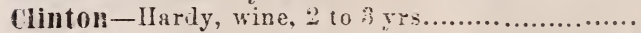

Concord-2 yrs., 1st class, or 1 year, extra selecterl

$$
\text { " 1st class layers, or cutting g.................. }
$$

.. Id class, hiyers and eutings.

. $\quad 3$ or 4 years,

$\therefore 00$

$\because 00$

$\because 00$

Creveling-Early, lst class, 1 year.....

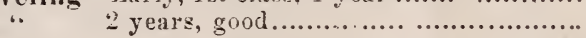

“3 or 4 years..

Croton-New, early, white, binch and berry large, delicious, productive, vigorous, 1 yr. Int..

Delaware-Single eyes and liayers, 1 year, ist......

$$
\begin{aligned}
& \text { “ } \quad 1 \text { year, } \begin{array}{l}
\text {. } \\
\text { " well rooted..................... }
\end{array} \\
& \text {.. } 3 \text { and } 4 \text { years, fine, trained............... }
\end{aligned}
$$

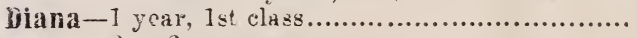

2 or 3 years, strong............................... 30

Dracut Amber-Finrly brown, 1 or 2 year..............

" ، 9 or 4 years.......................

Eumelan-Now, fine, early black, 1 st class $2-$ year

Hager-Or Arey. most excellent, rather carly. black, strong, 1 or 2 years................

“. ? or 1 year

Hartford Prolife-ULsT E.ARLY, 1 yr , Ist elass

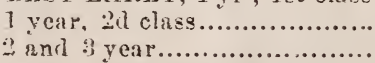

lixtra 3 and 4 years...............

Iona-(Dr. (irant) new, very fine, 2 or 3 ys., 1st class “ 1 year, 1st clase

Isabella-1 or : years, 1st class

$$
\text { " al class. }
$$

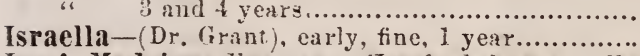

il clagy

Ives' Madeira-Karly as Hartford, hangs well; hardy, 2 or 3 years..................

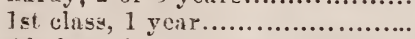
2d cluss, 1 year.

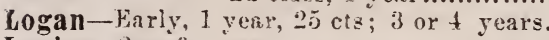

Louisa-2 ar is years. 
Aallany-Fine, white, 1 or 2 years............. 30

Miner's Seedling--(Tenango) Reddish amber, ......

Forth Imerica-

Fortan's Virginia-3 or 4 years.

1 vear, 1st class.................

2d class.

MACH.

Doz. 100. 1000.

30

$2 \pi$

$2 ;$

$50 \quad \$ 400 \quad \$ 2000$

25) $2.50 \quad 1: 00$

icious white.

1.5

Kebecea-Delicious white........................... 50

1501000

Rogers" Hybrids-1 year, Nos. 1, (Goethe), :3, (Massasoit.) 4, (Wilder, ) $5,7,9$, (Lindly, 12, 15. (Agawam, ) 19, $2.9 .95 .33,84,39,43.45 \ldots \ldots \ldots \ldots$ " or 3 years

salem-Good. 1 year.

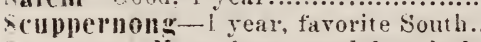

senasqua-خew. berry and buach large, black, hest, strong grower, 1 st cliss, 2 year..1 25

swatara-....................................... 15

Tirylor's Bullitt-2 or 3 years. strong............... 15

To Kalon-4 yrs. 40 ets each, $\$ 3.50$ pr dz; 1 or 2 yrs.

[nion Village -1 year...............................

Seeds and Labels.

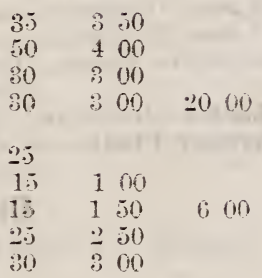

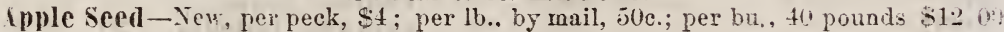
falycanthus Secd-Fresh, $\$ 1.00$ per quart.

Honey Locust Seed-New, 50c. per pound; 10 pounds

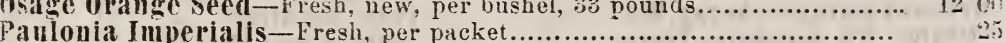

Peach Seed-Fresh, frozen, packed, per bushel, $\$ 2$; per barrel.............. 4 fif

Pear Seed-Fresh, per pound

Tree labels - Wirei, 20 cents per $100 ; \$ 150$ per 1,000 .

For Flower and Vegetable Seeds, see Special Catalcgue.

\section{ROOT GRAFTS}

Are Cions aud Foots grafted and tied together, ready for Ilnating in permaneut Vursery rows. From the ground up, therefore, the growth from the Cion is of the grafted species. This is almost the universai mode of starting Apple Nurseries.Dear, Cherry and Plum Root Grafts, (Standard not Dwarf) though less certain than Apple, are gaining in popularity.

Orders for special list of sorts MLST BE SEXT EARLY, with $\frac{1}{3}$ cash with orler. ii c offer the rery largest and best assortment we know of.

() ur Grafts are on first-rate Seedling Roots, are made in rery best strle, and packer? ready for shipping. Eren 50 s or 100 s of each sort will be put up at following prices. Eor smaller or broken lists, prices will be giren on application.

Apple-Orer:350 varieties, including, without extra charge, best Soctines, as Huntsman's Farorite, Kentucky Streak, Large Striped Pearmain, Oconee Grecning, Virginia Greening, Shockley, \&c.

Choice Easterx and Westers-Baldwin, Fallowater, Greening, Grimes, Rel Canala, Rome Beauty, Wagener, White Pippin, \&c.

In

Oldenburg, Fameuse, Haas, Hislop and Soulard Crabs, \&e.

Price Assortments.

Conlar Grafts-Which some prefer, but must be ordered early.

Tetofisky-Celebrated, very hardy.

Pear-Small lists allowed at 100 rates.....

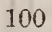
$s+100$ $\$ 400$ 1,000 $\$ 600$ $10,000100,000$

Cherry-Ey. Richmond, II. Duke, F....

Iorello. etc., with sweet rarieties. i) 00

$\$ 250$

400

400

800

in

$1 . ; 00$

$1200 \div 000$

$1200 \div 000$

$\begin{array}{llllll}300 & 1200 \quad 2000\end{array}$ 


\section{Stocks, Honey Locust and Osage Plants.}

Apple-1 -1 class, selected for grafting.

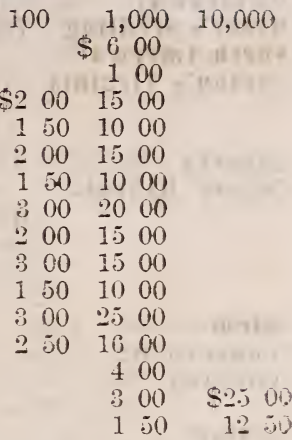

\section{Cions and Cuttings.}

Should be ordered in Winter, as most kinds start very early.

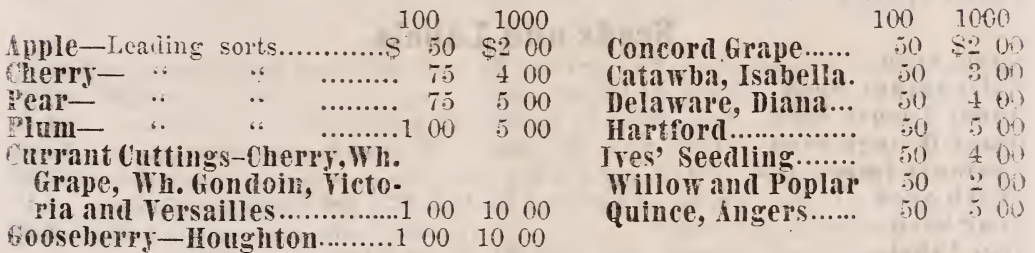

\section{EVERGREENS.}

IMMENSE STOCK, ALL NURSERY GROWN, AND MOSTLY THREE TIMES TRANSPLANTED.

On no soil we have erer seen, do Evergreens thrive any better than here.

\section{At Wholesale, Good Plants, But our Choice.}

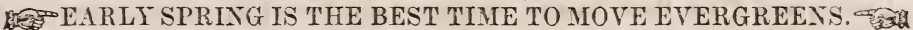

'Shelter very small Evergreens the first year or two, with brush or lath screen, 12 inches from the ground.

Arbor Vitæ-American or White Cedar, 6 to 9 inches, $1000 \$ 35$.

9 to 12 inch, $1000, \$ 45$

Each. Doz. $10 \%$

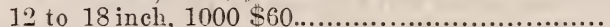

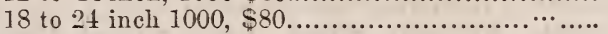

2 to $8 \mathrm{ft}$

575

15100

$8+4 i$

20150

; ( $(0)$

$30 \div 00$

700

100

3 to $4 \mathrm{ft}$.

40 \& 00

1400

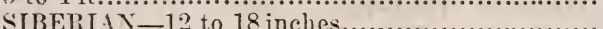

50400

2000

" 9 to 12 inch

$35 \quad 3 \quad 50$

$25 \quad 250$

BOOTHI., 12 to 15 in., BORE.ALIS, 9 to 12 in... 50 50 400

COMPACTA, 12 to 18, PUMILA, 12 to 18 inches. 75

ELEGANTISSIMA, 8 to 10 , ERICOIDES, 12 to

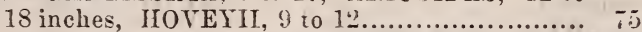

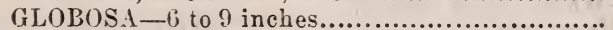

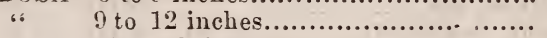

". 12 to 18 inches..............................

ORIENTALIS (Chinese) 4 to 6 in. 
TOM THUMB-4 to 6 inches

Balsam Fir-4 to 6 inches.

6 to 9 inches

9 to 12 inches.

12 to 18 inches

18 to 24 inches.

2 to 3 feet

3 to 4 feet.

Box-Dwarf, for Edging

TREE-Myrtle leaved.

Hemlock-Beautiful native, 6 to 9 inches.

9 to 12 inches.

12 to 18 inches.

18 to 24 inches,

2 t.o $2 \frac{\pi}{2}$ feet.

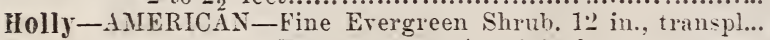
Forest grown, 4 to 6 inches.

Juniper-AMERICAN-3 feet. 6 12 inches.

CRACOVICA-6 to 9 inches.

9 to 12 inches.

GLAUCA-6 to 9 inches.

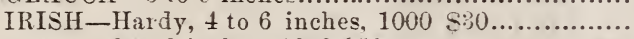

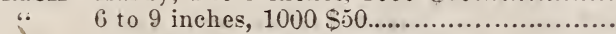

$\therefore$

“9 to 12 inches.

، 12 to 18 inches.

“ $\quad 18$ to 24 inches

، $\quad 24$ to 30 inches.

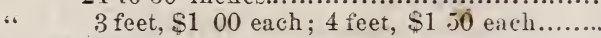

PYRAIIDAL -9 to 12 inches..........................

$$
\text { "6 } 6 \text { to } 9 \text { inches..... }
$$

SWEDISH-Hardy, fine, 12 to 18 inclies.

" 2 feet $50 \mathrm{c} ; 2 ?$ feet $75 \mathrm{c}, 3$ feet $\$ 1$ each..

TRAILING OR PROSTRATE-Most beautiful native.

9 to 12 inches.

Pine-AUSTRIAN-1 year seedlings, $1000 \$ 5,10,000-40$

4 to 6 ind $1000-1,000$.

4 to 6 inches, $1000 \$ 1,10,000 \$ 60 \ldots . . . . . .$.

"، 6 to 9 inches, $1000 \$ 10$

“. $\quad 9$ to 12 inches, transplanted $1000 \$ 30 \ldots \ldots$.

.. $\quad 12$ to 18 inches, $1000 \$ 80$

. $\quad 18$ to 24 inches

" 2 to 3 feet,

،. 3 to 4 feet

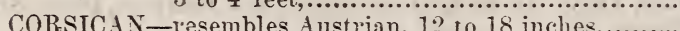

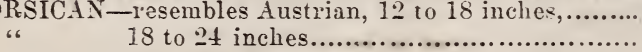

،

6 to 9 inches, 2 years

DWARF-Mountain, (P. Montann,) 9 to 12 inches,.......

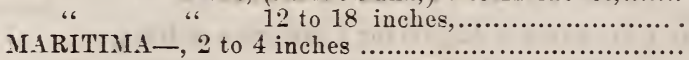

NORWAY OR RED AMERICAX-12 to 18 inches..........

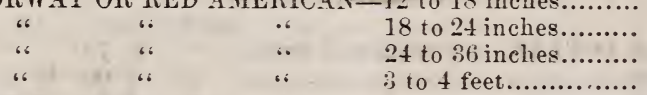

PITCH, (Rigida) -18 to 24 inches.............................

“6 .. 2 to 3 feet..........

“ .. 3 to 5 feet

SCOTCH-fine, 1 year, $1000 \$ 4,10.000 \$ 3 \tilde{s}$

" 4 to 6 inches, 2 years, $1000 \$ 7,10,000 \$ 50$

\begin{tabular}{|c|c|c|c|c|}
\hline & 1 & 00 & $\$ 6$ & $; 0 \%$ \\
\hline 1.5 & 1 & (1) & & 0 \\
\hline$\because 0$ & $\ddot{2}$ & (4) & 11 & 10 : \\
\hline$: 30$ & 2 & (1) & & \\
\hline 40 & 4 & 00 & & \\
\hline 60 & 5) & 00 & & \\
\hline 7.5 & 8 & (in) & & \\
\hline 30 & 3 & (0) & & \\
\hline & & $3 . j$ & & 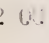 \\
\hline -2) & 1 & $\begin{array}{c}50 \\
00\end{array}$ & (i) & ; 0 \\
\hline 20 & 1 & (i) & 11 & 10 \\
\hline 30 & $\because$ & .010 & & \\
\hline 4i) & $\ddot{3}$ & 50 & & \\
\hline (3) & 4 & (11) & & \\
\hline 3.5 & :3 & 011 & & \\
\hline 10 & & (ii) & & 11 \\
\hline 15 & 1 & (H) & 0 & (C) \\
\hline 51$)$ & 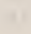 & & , & \\
\hline 20 & & & & \\
\hline 20 & 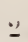 & (0) & & \\
\hline & & & & \\
\hline$=0$ & 1 & $\because 0$ & & $\therefore 1$ \\
\hline $2 \overline{-5}$ & 1 & .50 & 10) & 6 \\
\hline 40 & :3 & 181 & & \\
\hline i0 & -1 & (ii) & 20 & 18 \\
\hline$\because ;$ & $i$ & (ii) & $: 31)$ & \\
\hline 40 & 3 & (1) & & \\
\hline$\because \square$ & $\ddot{\prime}$ & .01 & & \\
\hline , & 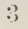 & (111) & & \\
\hline
\end{tabular}

$10 \%$

if 9

of

1110

(a)

(i) 13

11 (3)

41

$\div$

412

is 0

i) 15

20

(1) is. 


\section{HVETGREENS-CONTINUED.}

Pіне-COTCII-6 to 9 inches

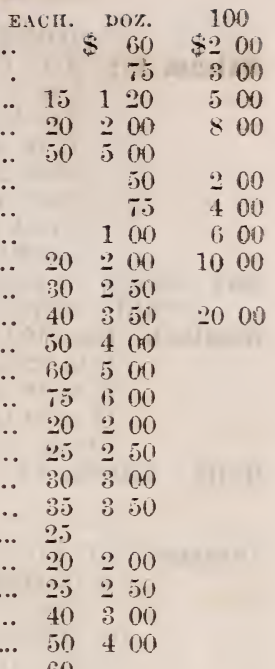

ged cedar$$
\text { .. 9 to } 12 \text { inches. }
$$

1:) to 18 inches, transplanted, $1000 \$ 35$.

18 to 24 inches, $1000 \$ 60$.

2 to 3 feet.

WIIITE- 4 to 6 inches.

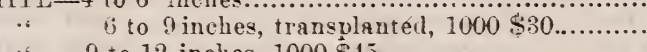

9 to 12 inches, $1000 \$ 45$.

. 12 to 18 inches.

.. 18 to 24 inches.

$\therefore \quad 2$ to 3 feet

.. 3 to 4 feet.

.. 4 to 5 feet

$\bar{v}$ to 6 feet

12 to 18 inches.

18 to 24 inclies,

2 t. 3 feet.

3 to 4 feet

vili-ELROPEIN-A fine Shrub. Juniper, 12 to 18 inches.....

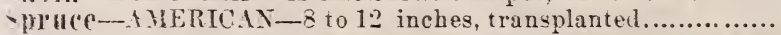

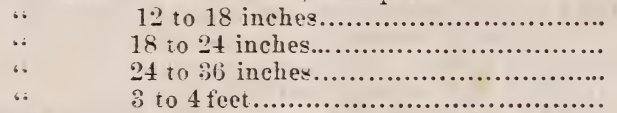

Fuli $1 \mathrm{Y}-1$ year, fine. $1000 \$ 3,10,000 \$ 20,4$ to 6 inches, 2 yenrs, $1000 \$ 5,10,000 \$ 40$.

3 to $\mathrm{f}$ inches transplanted, $1000 \$ 10 \ldots .$.

6 to $?$ inches, seedlings, $1000 \$ 12.00$, $10.000 \$ 110$.

1.6

6 to 9 inches, transplanted, $1000 \$ 15$.

9 to 12 inches, transplanted,.....1000 $\$ 2 *$

12 to 18 inches, bushy, $1000 \$ 40 \ldots . . . \ldots$.

18 to $2 t$ inches, $1000 \$ 140, \ldots \ldots \ldots \ldots . . . . .$.

-) to 3 feet, bushy

3 to 4 feet, fine.

TEW EYERGREEYS. - CEPHALOTAXUS FORTUNEI AND JAPONICA, 10 $\because 1:$ inches, 50 to 75 e. CUPRESSUS LAWSONIANA, 6 to 9 inches, $\$ 2$ doz. ; 9 to 12 whes, 50 per doz.. CYPRESS, NoOTKA SOUND, (Thuiopsis Borealis,) 6 to 9 mehes, 25e. ench. KALMIA, LAUREL, 2 sorts, broad-and narrow-leaved, 12 to 20 thes, 2 cts. each, $\$ 2.50$ doz. MAGNOLIA GRANDIFLORA, 9 to 15 inches, ite. to 7.e. PICE.1 PICHT.1, 12 to 18 inches, 50c. to 75c. PINUS CEMBRA, $\because$ to 18 inches. To each. RETINOSPORA. DOLABRATA, LEPTOCLADA, and LW IIOS 9 to 12 inches, 50 to $75 \mathrm{c}$ RODODENDRON, $\$ 1$ to $\$ 2$ each. TAXUS YPICPA, or Erect Yow, 1 foot, 50c each. Also several new Junipers, Pines, Spruces, sew ic.. rille to $\$ 1$ each.

\section{ORNAMENTAL TREES.}

(i) for $\frac{3}{3}$ the price of $12 ; 50$ for $\frac{2}{3}$ the price of 100 .

Abele-OR SILVER POPLAR-1 year, 2 to 3 feet... 4 to 6 feet. ij to 8 feet. EAC I. $\therefore$

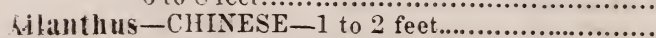
AImOnd-LARGE DOUBLE FLOWERING.

\begin{tabular}{ccccc} 
AC II. & Doz. & \multicolumn{1}{c}{100} \\
& 5 & 75 & & \\
15 & 1 & 00 & $\$ 6$ & 00 \\
20 & 1 & 50 & 7 & 00 \\
15 & 1 & 50 & & \\
25 & 2 & 50 & 12 & 00 \\
50 & & & & \\
35 & 3 & 00 & &
\end{tabular}
1000 Alple-CHIXESE-Db'l. Fl., Red, Spectabilis, showy, 


\section{ORNAMFN'TAY 'TREES-CON'TNUED.}

Ash-A.HERICAX WHTTE-Very hardy, 4 to 12 inch

1 to 2 feet.

2 to 3 feet

?) to 5 feet

it to $T$ feet.

7 to 8 feet

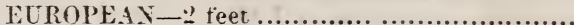

3) to 4 feet.

4 to 6 feet................................

6 to 8 feet.

- EXGLISH---Splendid new sor is, Broad-fruited,

Dwarf, Flowering, Gold-Barked. Imbricated,

Myrtle-Leared, Punctata, Rufa. Single-I; ved,

Sharp-Leared, Willow-Leaver, Walnut Lived..

Becch-AMIERICAN-Transplanted, 6 to 9 inches...

(1) to 1:2 inches.

، 12 to 18 inches.

EUROPEAX-s to 12 inches, transplanted....... ، 1 ? to 18 inches.

PURPLE LEAVED - 3 to 4 feet

BiPch-AIERICAX WHITE-2 to 4 feet

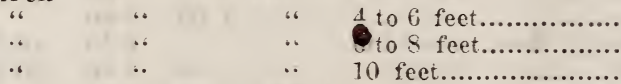

BLACK and YELLOH 3 to $j$ feet............

10 to 16 feet.......

.. ECPOPEAN WHITE-See Weeping Trees.

Plack Halnut-Most valuable nut and timber tree.

. 1 to 2 feet transplanted...............

3 to 4 feet.

4 to 6 feet.

6 to 8 feet...

10 to 12 feet.

Catalpa-Superb tiowers, 6 to 12 inches...................

12 to 18 inches.

2 t.o 3 feet

:3 to 4 feet.

+ to 6 feet

8 to 10 feet.

Chestuut-A.MERICAN-8 to 12 inches

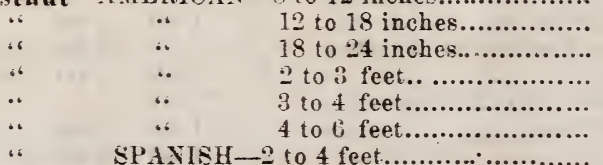

Coruns-Dogwood, white fiowers, 2 to 3 feet transp.

Cotton rood -3 to 4 feet.

\pm to 6 feet.

6 to 8 feet.

10 to 15 feet.

Cypress-DECIDUOUS-Mlost superb, hardy, 2 to $3 \mathrm{ft}^{*}$

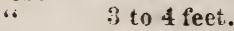

“ 4 to 6 feet

Elm

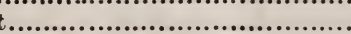

6 to 12 inches

1 to 2 feet transplanted.......

is to 4 feet, transplanteri......

4 to 6 feet.
Each. Doz,

1010

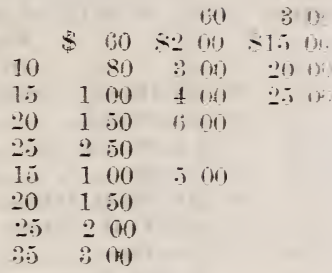

75

200

100

$\because 0 \quad 200$

$15 \quad 150$

8010

25

100

10

15

2.5

ti)

15

75

1. $00 \quad$ if 00

150800

200

$40(1)$

1 (1)

10

60

$\therefore 0$

\$?

i5

1 (x)

(3) 00

2i) 1)

1 i0

50

200

ij 10

41) (1):

;i)

or

(i)

150

(1) (1):

75

15 100

$20) \quad 1 \quad 0$

25) 200

千0 300

60

80

$\therefore 0$

]. 00

2 (i) 1ii tais

1.5

20

2.5

25

2.5

$1: 0$

150

$\because 00$

$\div 50$

200

60

15

100

$\therefore 00$

$+00$

if 00

700

800

1.500

20

120

$\because 00$

$250 \quad 7200$

$25 \quad 250$

35 $300 \quad 1500$

50

$+00$

$\because 000$ 


\section{GIRNAMENTAL TREES-CONTINUED.}

HII-AMLR. WHTE-f to 8 feet.

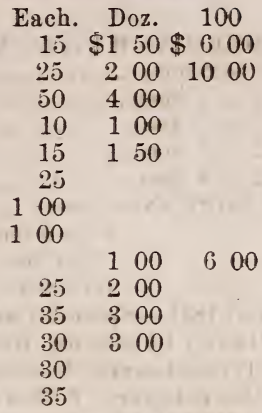

English Walnut -12 to 18 inches $\ldots \ldots \ldots \ldots \ldots \ldots \ldots \ldots \ldots .$.
Hackberry-4 to 6 feet ...................................

8 to 10 feet.

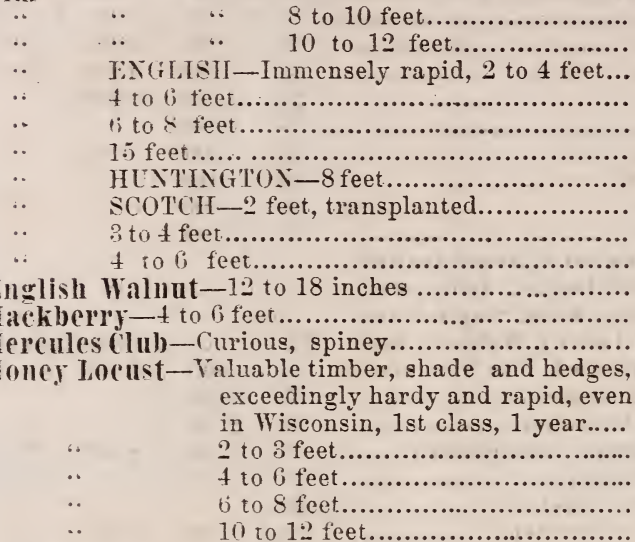

Hop Tret-12 inches. exceedingly hardy and rapid, even in Wisconsin, 1 st class, 1 year..... 2 to 3 feet

ti to 8 feet...

Horse Chestuut-Succeeds fairly West, 9 to 12 in.

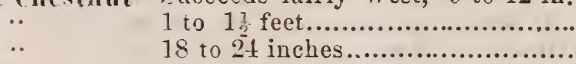

- to 3 feet.

Indas Tree-Or. Ried Bud, 12 t.o 18 inches.

Junebelpy-Shad or Service Berry. 8 to 12 inches...

Kentucky Coffee-Hardy eren in Wis., 2 to 3 feet...

Iarch-ECROPE.AY-1 yr., 2 to 4 inches, 10,000, \$25

$$
2 \text { years, } 1 \text { foot...................... }
$$

Larch-LIERICAX-18 to 24 inches.................

laburnum-Common Golden Chain, 6 to 12 inches..

ENGLISH and SCOTCH -9 to 12 inches.........

Linden-AMERIC.LN-2 to 3 feet.

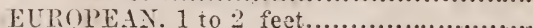

$\because 00 \quad 1000$

$$
2 \text { to }: 3 \text { feet. }
$$


PURPUREA-2 feet

FACH. DOZ.

SOULANGEANA - 2 feet.

75

TRIPETALA 3 to 5 feet.

Uaple-ASH LEAVED_(Box Elder, very rapid, hardy, beautiful, 9 to 12 inches

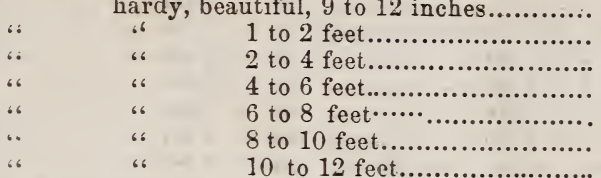

NORWAY--Esteemed European var. 9 to 12 in.

" 1 to 2 feet.

2 to 3 feet.

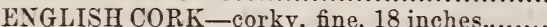

PURPLE SYCAMORE-LEAVED-1 to 2 feet..

SILVER LEAVED or SOFT-Great for shade and timber, most rapid, 6 to 12 inches.

Free by mail

1 to $1 \frac{1}{2}$ feet

Free by mail

18 to 30 inches.

$$
\text { (5) }
$$

4 to 6 feet, $10,000 \$ 125$

(j to 8 feet, $10.000 \$ 200$

8 to 10 feet, $10,000 \$ 300$

10 to 12 feet, $10,000 \$ 400$.

12 to 14 feet....

$1 \pm$ to 20 feet.

SUG.1H-6 to 9 inch, transpl'd................... "6

9 to 12 inches.

1 to $1 \frac{1}{2}$ feet

$$
\text { 4. to } 6 \text { feet. }
$$

SYCAMORE-LEAVED-9 to 12 inches.......... .

1 to 2 feet

Hountain Ash-AMERICAN-t feet.

EUROPEAN-6 to 12 inches............

2 to 4 feet.................

4 to 6 feet....................

6 to 8 feet.

ACREA, CRATEGIFOLIA, LATI-

FOLIA, VESTATA, 2 to 3 feet........

OAK LEAVED -2 to 3 feet............

3 to 5 feet ..................

0 aks-Fine, named sorts, 1 to 2 feet, transplanted... 2 to $i$ feet....................... 3 to 4 feet........................

Paulonia-i to 5 feet

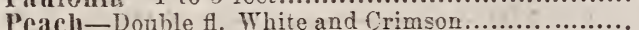

Pecan-Native, hardy, 1 to 2 feet.......................

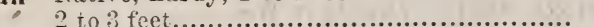

Persimmon-hardy, fine, 6 inch.....................

2 to 3 feet...................................

Poplar-ASPEX-LEATED-4 to 6 feet................

LOMBARDI -3 to 4 feet...................

4 to 6 feet

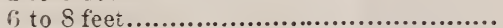

8 to 10 feet...................................

10 to 15 feet, $30 \mathrm{c} ., 83 \mathrm{pr}$, doz., 15 to $20 \mathrm{ft}$.

Salisburia-OR JAPAX JINKO-4 feet $50 c ., j$ feet,

6 feet.

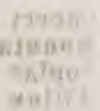


Sweet Gum-Beautiful, 2 to + feet

FАС. vOZ.

100.

(10,0)

sycamore-AMERIC.AY-(Buttonwood)-.2 to $4 \mathrm{ft} . . \quad 1,5100$

4 to 6 feet

20

6 to 8 feet

$150 \$ 1000$

Fulip Tree-WHITEWOOW-1 to 2 feet

i) 00

150

$\because$ to 3 feet............... $\because 0 \quad 200$

3 to + feet................. 25 $\quad 250$

$t$ to 6 f feet................. $80 \quad: 300$

6 to 8 feet

$40+00$

Virgilia-2 to 4 feet

(3) $30(0)$

Willow-GOLDEN-Rapid, showy, 1 to 2 feet........

3 to 4 feet.

75

100

(i) to 8 feet,

1 jo

8 to 10 feet

1:)

$3(4)$

$2(1)$

10 to 12 feet.

$21 \quad \geq 00$

$25 \quad 20$

$+(3 i)$

$x$ (b)

LAUREL LEAVED-Beautitul, I to 4 ft..

4 to $f$ f feet.

50

$15) \quad 1(k)$

$1+(n)$

;) (6)

8 to 10 feet.

-3) 20

$\therefore(H)$

OSIER-( P'urpurea) - Basket Willow. most esteemed sort, strong, $1 \mathrm{gr}$. plants strong, $2 \mathrm{yr}$. plants.

FIXG-LEAVED-Pretty, 4 to i feet.........

ROSEMARY-IEAVED-12 to 18 inches...

$$
\geq 10+\text { feet.......... }
$$

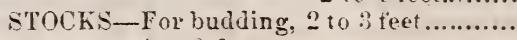

\pm to $i$ feet

TRIANDRA-Immense grower, + io it th., 10 to 12 feet ...................

WHITE or GRAY-1 to 2 feet..................

4 to 6 i teet

$\frac{20}{15} \quad \ddot{1}(0)$

i1) (10)

(i) to 8 feet

\section{Weeping Trees.}

Beech-WEEPING

Birch-EUROPE:<smiles>[C]#CCCC#C</smiles>

..

.6
..

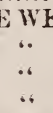

Each.

Dor.

1(1:) .$\$ 200$

CUT-LFA

18 to
4 to
ij feet..............

Ti:

Ss $(00)$

S.i) $\{x$

i) 10 4 feet.

$4(0)$

2 to 3 feet.

30 :: 00

20.5

cherry-Weeping

Mountain Ash-WELPING.

PING-4 to bi feet.

jo

$1 ; 0$

Poplar-WEEPING-GRANDIDENTATA l'ENDLLA ....... 150

WIIOW-NEW A.YERICAN WEEPING.................... I 100

COMMON WEEPIXG 4 to 6 feet..................... 20

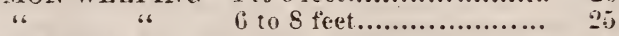

KILMARNOCK.................................. 1 10

$1 ; 0$

i in

$\because(x)$

\& $(x)$

WISCONSIN WEEPING-Perfectly bardy in Wis.

2 to 3 feet, $\$ 3$ per $100 ; \$ 25 \mathrm{pr} 1000 ; 4$ to $\mathrm{C} \mathrm{ft}$.

if to 8 feet 


\section{[17] \\ ORNAMENTAL SHRUBS.}

6 for the price of $12 ; 50$ for $\frac{2}{3}$ the price of 100 .

Acacia-Rose or Moss Locust.

Each.

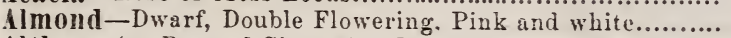

Aithea-(or Rose of Sharon)-Named rarieties, 1 year......

“Speciosa-Strong plants.

1

Azalea-swamp Pink, fine...................................

Berberry-Red-fruit'd, invaluable Forth for fruit, ornament and hedges, strong, 2 to \& feet, $1000 \$ 30 \ldots \ldots . . . .$.

Purple Leaved, 4 to 9 inches.........................

¿ to 18 inches, 80c. per (loz., 100, $\$ 6 ; 3$ feet...

Calycanthus-Sweet scented shrub, 1 st class.................

24 class, 30c., 83 per doz., 610 inch tine..

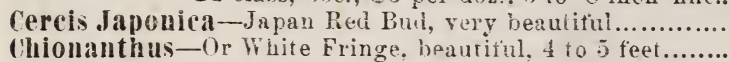

Clethra-White, fragrant ....................................

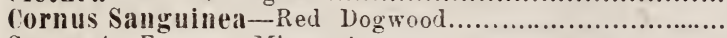

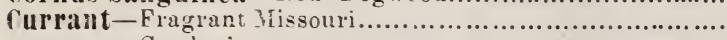

Goriton's.

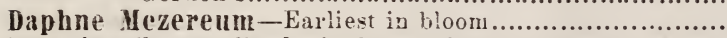

Deutzia-Crenate-l'ved, single and dbl, fine, hardy, strong

. (Scabra) Rough Leaved and Fortuneii..............

6 Gracilis..

Eleagnus-Argentea and Hortensis..............................

Euonymus-Strawberry Tree, Burning Bush, 4 to 12 inches

1 to 2 feet

25

$35 \quad 300$

$25 \quad 2 \quad 50$

$20 \quad 150$

40350

$\$ 1000$

15100

30

400

$30: 00$

$40+00$

100

200

20 (a)

100

40.300

25250

25200

25

25

40

400

100

150

50

25

30

50

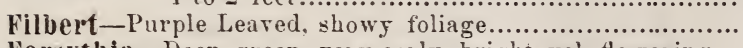

Forsythia-Deep green, very early, bright yel. Howering...

Iloneysuckle-Bush or Uprigbt, six named sorts, strong....

Hop Tree-Trefoil, pretty (see ornamental trees)..............

IIorse Chestuut-Dwarf.

Ifydrangea-Cordata, Japonica, Quercitolia...................

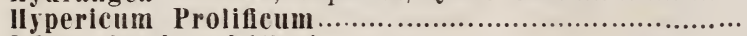

Lilac-Purple and Siberian....................................

" White and Double-Flowering Purple,..................

، Josikea nnd Red French................................ 50

Yoose or leather Wood-Strong............................. 25

Prunus Spinosa and Trilobata............................. $\quad \delta 0$

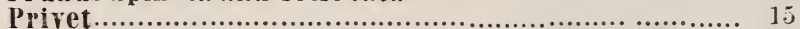

Purple Fringe or Smoke Tree................................ 40

Quince-Japan Scrrlet and Blush............................. 50

Snowball-2 to 3 feet, $30 \mathrm{c}$. each, $\$ 3.00$ per loz. : 3 to 4 feet: 40

Snowberry - Symphoricarpus occilentalis ..................... 25

Spirea-all hardy, Billardi, pink, Van Houtii................ 25

Elm-Leared. Ulmifolia, white...................... 25

Reevesi, Salicifolia, white, Opulifolia, stroug.......... 25

Fortuneii, and others.................................. 25

Syringa-Hock Orange, several named sorts.................. 25

Tamarix-African, pink flowers, popular, strong................ 25

Tree Paeony-Medium ......................................... 1

Tree CranberrJ-Or High Bush, strong......................

Wigelia, Alba................................................... 30

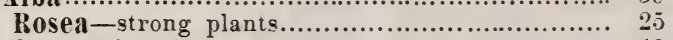

Gronewigenil-Dark flowers, strong grower...... 40

200

$2(k)$

1 (ot)

400

400

400

200

150

100

i) $0(1$

10 (n)

150

400

150

500

fi 00

250

50

1000

500

300

250

Koses, Greenhouse, Bedding, and all choice and tender plants, should be packed separate from trees, shrubs, and bulky articles, and be sent by mail or express. Therefore, please write orders for such planis on a separate sheet. 


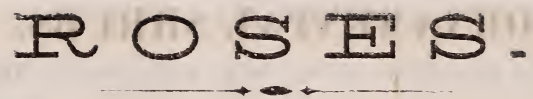

Lach. Dor.

100

June-Blush, lied, White and bar' rarieties, named, strong... $30 \$ 300 \$ 1800$

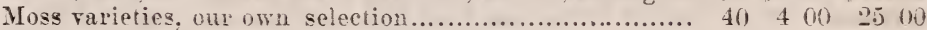

Striped, York and Lancaster ............................. \$.j

White alone, Mal Piantier, snowball, Hyb. White, de... 41) 400

Harrison, yellow............................................ 50 400

Climbing. our selection...................................... 80 ; 00 15 00

Gem of the Prairies, good plants.............................

Hybrid Perpetual-No. 1, Tarieties our selection, strong plits 40 औ

Ifybrid Perpetual Moss. our selection.....

Hybrid Perpeinal White, our selection.....

Hybrid Perpetual. unaned, the rarieties.

o. 3, well established, lir.o assortment,

after April 1.5th, 1000,50

Yonthy Roses-Large assortment, all classes, strong, well establi

plants, including Bengal oì Chira, Bourbon.

Toisette and 'Tea rarieties. our selection......

No. 2-, gool assortment.

Xo. 3, well establisherl. 1000 50

Harshal Yell-Superb Yellow Yoistte. strong flowering plauts

Strong No. 2 plarts...............................

$30 \quad 300 \quad 1.500$

21120010 (1)

$150 \div 0 i$

$50+610$

(3) 3 (i)

Sto Special lists of Roses miay be subject to special or Retail rates.

\section{VINES AND CRLEPERS.}

6 for $\frac{2}{3}$ the rive of $1 \%$.

Eaclı, Doz.

Ampelopsis-Virginia Creeparor American Ivy, beantifiul. rapid grower, no flowers, native..................... si sil

Ampelopsis-Tricolor, rariegated leaved, fine................

Bignonia-Trumpet Creeper.25

6 Girandiflora..........

Celastrus or Stafi Tree.........

Clematis-Apiifolia, Louisat.

Sophia and others, choice....50
Clematis - White and Blue Flowering, $100, \$ 10 \ldots \ldots \ldots . .20 \$ 1$ की

Honeysuckle--Frag't Mouthly

Japan Erergreen..............

Yellow and Scarlet Trumpet

or Coral, and others........... 30

200 Periploca-Tirginia silk vine 2.5

2 (6) Wistaria-Glycine, American, 20

2 of Chinease Blue.................. is

\section{HARDY HERBACEOUS PIANTS.}

6 , for $\frac{2}{3}$ the price of $12 ; 50$, tol $\frac{3}{3}$ the price of 100 .

Each. Doz.

Achillea-Ptarmica Alba.. 25 250

Aquilegia-Columbine....... 20 200

Antirphinums-Sorts....... 20 150

Armeria-Rose and White... $2.5 \quad \therefore \quad 50$

Arundinaria--Ribhon Grass 1.5 100

Istilbe-Spirear Japoniea.... 25 :2 in

Bellis - Perrennis, Daisies, Douhle, Assorted Colors... 20

Callirhe - Slinwy ............. 25

Campanula-10 choice single and double sort $1(0,8-5$

Carnations-Dhl and Stripeil 20

Catananche -3 aorts ....... 20

Delphinium-... sorts........ 25
Lily, fragrant

Geum-Four sort.............. 25 200

(iypsophilea-2 sorts........ 20) 2 on

Hemerocalis-? sorts ...... bi

2 .

$\because 00$ Hollyhoek .................... 25 25 50

1 5! Iberis-Sempertirens ........ 25 25

2.50 Ipumopsis-4 sorts............ $20 \quad 200$ 
Each. Doz.

Liatris-spicata, .............. $20 \$ 200$

Jinum-Perennial Flax...... 20

Lupinus -3 sort s............... 20

Lyehnis-1 sorts

200

200

200

Oenothera-Riparia, Awarf.

Taraxifolia, yellow............. ¿j 250

Faparer-Bracteatum and Orientale $100 \$ 7 \ldots \ldots \ldots \ldots . . .20 \quad 200$

Penstemon.................... $25 \quad 250$

Paconies-Large, fine col., 30 named sorts $\$ 12$ per $100,2.5 \quad 250$

Hixed, choice, $\$ 8$ per 100 .. In 150

Phloxes-fine named sorts, 100510 .

Phygelius--Capensis........ 25

Polyanthus-Primrose....., no

150

2.50

200

\section{HANKS. CONATUED.}

Eaeh. Doz.

Potentilla-3 sorts............ 20 \$2 10

Rocket-Sweet................. 20 20 (n)

sireet Wiliam-Dbl \& Sing $20 \div 00$

Very choice, $100 \$ 8$.

Stachys-Lanata............... $25 \quad 250$

Statice-Tartarica ............. 25050

Veronica-Elegans.............. 20200

\section{MEDICAL HERBS.}

Latender

200

Rosemary 20

200

Bue ............................ 25

Sweet Marjoram............. 20

Wormwood ................... 20

\section{Flowering Bulbs and Plants.}

Wahlias-Large, choice, proved collecticn, 100 or more sorts,

Each. Doz.

with names, Dry lioots..............................

without names........................................... 20

Fot Plants, (in Spring,) ........................... 15

Gadiolus-Groorl collection. fine roots, choice named............. 20

Choice mixed from named varicties, siroug roors... 15

..
"Gandareusis, Brenchleyensis, Floribundus, Psitta-
cinus and Choice mixed, strong roots............ 10

$\$ 800 \quad \$ 15$ on

$200 \quad 1000$

$150 \quad 800$

$250-1500$

$150 \quad 1000$

Uadeira Vine-Climbing.................................... 10

$60 \quad 500$

Tiger Flowol-Mexican Yellow and Red, beautiful.............. 15

Tuberoses-Double White, strong, flowering bulbs............. 15

" To. 2. all good roots, and Single White, strong........

.. $\quad$ No. 3 , for planting.

\section{LILIES, HARDY.}

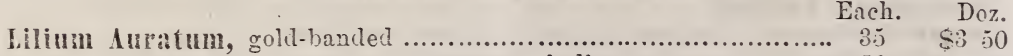

Candidum, (old White Lily), pure white, very fragrant....... 2000

Chalcedonicum, brilliant scarlet............................ 60 6) 00

Longiflolum. pure white, with large trumpet shaped flowers $20 \quad 200$

Tigrinum, (Tiger Lily), orange-spotted, ..................... 20 20 0

Vmbellatum, orange-spotted................................ $25 \quad 250$

Erectum, yellow spotted................................. 25 250

Venustum, orange buff, handsome............................. $40 \quad 400$

Lily of the Yalley-(Convallaria Majalis,) choice, favorite exquisitely fragrant, perfectly hardy, a fine stock, 100 \$5.

\section{HARDY BULBS.}

nerlant from October to Winter, not in Spring.

TULIPS, HYACINTIS, CROCES, CROWN MMPERIAIS, FRITILLARIFS, IRIS, JOYQUILS, NARCISSLS, SYOWDROPS, \&C. 


\section{Greenhouse and Bedding Plants.}

6 for $\frac{2}{3}$ the price of 12 .

\section{A Very Iarge Fine stock.}

Bedding Plants are designated hy a $\left(^{*}\right)$, and are most desirable for decorating Beds or Borders, blooming until frost.

DSF Prices named are for regular shipping size. Selection of varieties to be ours. Many other varieties at retail.

N. B.-Descriptive Plant Catalogue issued each spring.

* Abutilon-12 varieties. A. Balangier, Alba, Baron Humboldt Each. Doz. 100. Intermedia, Malak off, Santana, Striatum, Thompsoni, also the beautiful trailing or weeping Vexillarium family V. Carminata, Elegans, Grandiflora, Mesopotamicum..........

* Achyranthus or Iresene-6 varieties, Acuminata, Aurea Retieulata, Borbonica, Gilsonii, Lindenii

Achania Mollis or Malraviscus Arborea. - Shrub, old, farorite, profuse winter and summer blocming, Hibiscus like scarlet flower, will bed out well.................... * Ageratum-Album, Celestinum, I'rince Alfred, Tom Thumb, Variegata.

*Amaranthus-Tricolor and Yagnifica, New.....................

Ardisia-Crenulata

* Irtemisia Stellaris-Very white leaves and stems, half trailing, fine for baskets, edging for flower beds, \&c...

Azaleas-Beautiful, bov. to $\$ 1.00$ each, per doz. $\$ 6$ to.......... Begonia-14 rarieties, Fusioides. Parvifolia, Rex, Rosea elgans, Semperflorens, Silver Queen. \&c....................

* Bourardia-6 varicties, Aurantiaca, Elegans. Florabunda, Hogarth, Leiantha, Van IIoutei, strorg plants..............

* Bonssingaltia-Tar. Succulent 12 to 15 inches, beautifully variegated green and white foliage, habit compactmost desirable for bediling................................

Bridal Rose-Rubus, fl. pl. also Granditiora...................

* Brugmansia Knightii

Cactus-Ackermanii, Empress Eugenie, Epiphyllum Truncatum, Grandiflorum, Jenkinsonii, Speciosa, \&c...........

*Caladium or Colocasia-10 varieties, Bicolor, Esculentum? Marmoratum, Pictum, Wightii. and others.................

Calceolaria-Hybrida and 6 named Shrubby, sinowy........... Calla-Ethiopian Lily

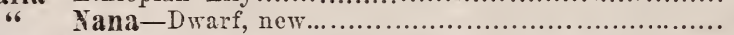

Camellia-Japonica, many sorts and sizes, pr dz. $\$ 10$ to ........

*Cannas-Indian Shot, sorts.................................

* Carnations-Tree or Monthly, fine sorts.......................

*Centaurea-Candida 50c ; Gymocarpa.........................

Centradenia-Rosea, Floribunda, Granditicra......................

*Chrysanthemums-60 fine eorts including 20 sorts of Chinese and New Japan........................................

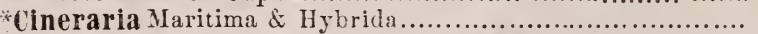

C'itrus-Orange and Lemon, Lksox-Chintse. Jewish, Large Lemon, Variegated Leaved. Orasif-Hybrida, Mandarin, Myrtifolia, Maltese Blood, Otaheite, St. Michael, Tangerine, Variegated, strong plants 50 e to...................... our choice......................................................

$\begin{array}{lllll}50 & & & & \\ 50 & 4 & 50 & & \\ 20 & 1 & 50 & 7 & 00 \\ 20 & 1 & 50 & 7 & 00\end{array}$


Cyclamen-Persicum 50c:2ni size, choice.

\section{Cyperus Alternifolius}

Variegated, beautiful, ...

Daphne-Cneorum, $\$ 1$ each; Indica, albe $00 \mathrm{c}$ to

Dracena Terminalis-Single stem, paim-like shrub, superb, decorative. broad crimson, scurlet and green, always

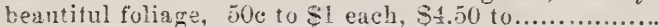

* Eupatoriam-Angustifolium, Arboreum, Elegans................

*Eugnymas-5 varieties. Argentea, Aurea Maculata, Sulpliurea Ifarginata, Tri-color, Variegata..................... Young. Stouky plants.

Fabiana-Imbricata

Ferns-Adiantum. Aspidium, Pteris...............................

Nigs-Brown and White, strong plants..........................

Forget-me-not-TRUE.

Fuchsias-Vagnificent collection, 60 sorts, ....................

Gardenia-or Cape Jasmine, 4 varieties, 40 to ..................

* Gazania-Sorts ................................................

*Geraniums - Balm, Citron, Myrrh. Peppermint....................

Apple, Lemon. Nutmeg. Pennyrayal and Rose Scented,

* Geranium-Zonale, most superb collection, over 100 rery best named sorts, Uld and Vew................. New Docble: Floweriyg, 20 choice named sorts, Auguste Ferrier, Capt. L'Hermite, Emily Lemoine, Gloire de Nancy, Vialam Rose Chasmante, Triomple Gragoriat, Tri. Lorraine, Tri. Thumesnil. ...

1. Henderson, E. G. Henderson, Inperatrice Eugenie, LaTesuve, Madam Lemoine, Maria Crousse, Mririe Lemoine, Victor, Wm. Pfitzer... Broxze, Golid axd Silyzr Edged, fine collection, Alma, Atraction, Bijor, Cluth of Gold, Golden Chain, Golden Fleece, Mountain of Snow, Mrs. Longfield. Silver Qneen, Queen Victoria. S other's Tri-color, Mrs. Pollock,

$\cdots$ IVy LeAred, Blushing Beatty, Fairy Belle, G olden, Ifolly Wreath, Pcltatum, Peltatum Variex:atum, Ec., 2.5 to.

Goldfussia Iatsophla-sirub, free, beautiful, pale blue, winter.

*Grasses - Variegat. Acorus Yariegata, Aira Cerulea, Festuca,

Hordium Jubatum, Glauca, Panicum Variegatum..........

* Gnaphaltum Lanatum-IIost excellent white downy trailer for edging, baskets, dc., contrasts beautifully with Achrranthus, Coleus, \&c.

Halbrothamnus-Elegans, tall growing shrub, for pillars or training, free, tube-like. red pandunt flowers..............

* Weliotrope-1:2 choice named rarieties.......................

IIeterocentum-11ba and Rosea, Shrubby, very free, white and rose. winter blooming....................................

"Ihibiscus -5 choice single and double sorts......................

Hoya Carnosa-Wax Plant......................................

Vuriegated..........................................

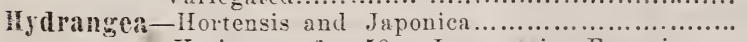
Variegata, fine 50c.: Imperatice Nugenic...... Jasmine-Yollow, Nuditlorum and Catalonian, fargrant...... *Jerusalem cherry.

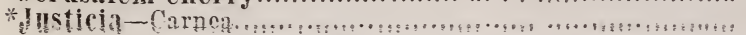

Each.
25
25
50
100
100

900

200

Doz.

$\$ 250$

250

450

100.

300

200

200

300

450

100

200

450

200

$\therefore 50$

200

200

$\$ 10$ co

10 


\section{GREFNHOLSE AND BEDIDIG HUITS-CONTINUED.}

* Lagerstremia-Crape Myrte,-eiegrnt shrub, Elegans, In-

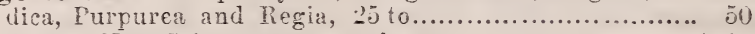

.. Tew Crimson, strong plants......................1 00

*Lantanas-Fine collection................................ $\approx 0$

Laurustinus-Showy, white, winter.......................... 25

Libonia-Floribunda.......................................... ergreen shrub........................................

Linum Trigynum-Shrubby, easily grown, free, neat, indispensable, winter yellow............................

* Ionicera-Aurea Reticulata, Belgica, Halleyana, Splendida, new Japan, hardy...

Doz.

100

$\$ 300$

$150 \$ \$ 700$

250

ㄴ 50

30300

25

250

1.) 00

Lopezia-Kosea, Minneata, rery beautiful winter.

Yahernia-Odorata

* Hanettia Cordata-Very choice, free flowering, vigorous, Heshy rooted climber, foliage acuminate, deep green, profuse tubular scarlet \& yellow summer \& fall flowers

Yespilus-Lequat, Japan Plum, superb evergreen, delicious winter fruit-beuring.....................................

* Vignonet - Eragrant ...........................................

Vimulus-Mosebata, (Mnk), and Hybrida

Mytus Communis-The True shrub Iyrtle, favorite olu greenhouse or window plant, fragrant leares and double white winter flower: fine plants..................

* Verember *oleandez-The Rexl, large, trained -4 to 80 inches.........

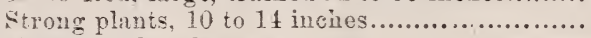
Joung stocky plants................................. Alba and Alba Duplex, young stocky ….......... White Double, \$1 : Alba large, and Yellow.........

Oxalis-4

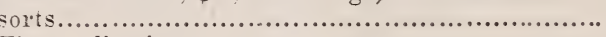

*Pansies-Fine collection..................................... Trifasciata............................................... *Hardy. free flowering blue...........................

Pampas Grass-Celebrated.....................................

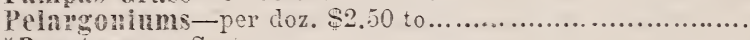

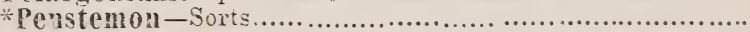

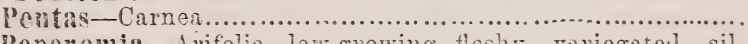

Peperomia-Arifolia, low growing, tleshy, rariegaterl, silvery white and green foliage, easily managed basket or pot plants...

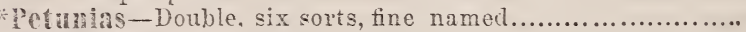

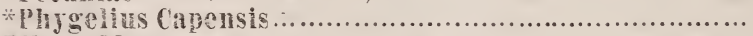

Pilea-Iuscosa .............................................

*Plumbago-Larpentae, Rosea, Zeylandica.......................

Poinsettia-Pulcher.ima.....................................

Young plants, .

Golden Feather...................................

Rissellia_. Tuncer, 
"Solanum-Capsicastrum

$\begin{array}{ccc}\text { Each } & \text { Doz. } & 100 \\ 20 & 5200 & 8800 \\ 30 & 300 & \\ 20 & 150 & 700 \\ 30 & 300 & \\ 75 & 500 & \\ 85 & 300 & 1200\end{array}$

Siphocampylus-Bi-color .........................................

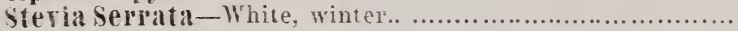

Taesonia-Manicata..............................................

Buchanani. Ton Folxemi,...........................................

Tritoma-Stiong, f...................................... purple and green foliage ................................

50 450

Tropeolum-Double Orange, very free, winter blooming greenhouse or window, also Single named rarieties, gay, indispensable climbers..............................

Ferbenas-Over 100 sorts, strong plants, $1000 \$ 40$.

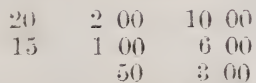

Veronicas-Evergieen, winter and summer flowering shrubs. colors white, purple and crimson shaded, Itkinsonii,

Devoniana, Imperialis. Rubra Carminata................

*Vinca- (8) Posea, Alba and Alba Picta.........................

Violet-Double 'white, Czar: leapolitan, Schonbrunn, Tree. King of the Violets..

\section{TASE AYD BASIET PLAYTS.}

ress See remarks on sizes and prices, under head of Greenhouse and Bedding Plants

\section{6 for $\frac{2}{3}$ the price of $1:$.}

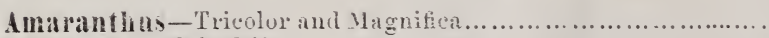

Eitit. Uoz, 10if

Ampelopsis Veitchii.

Balm-iariegated. sweet

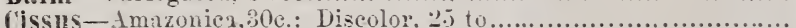

Convolralus Inaritanieus.

Ferns-Tarieties, beantiful...

Graqapla-sempervirens, pretty.

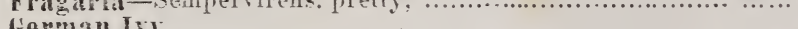

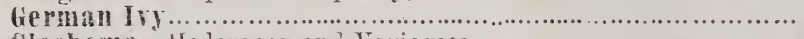

flechom $n$-Hederacen and Variegata ..............................

Hedera, Iry-Sorts, $2 \mathrm{ft}$

\begin{tabular}{|c|c|c|}
\hline & -10 & \\
\hline 50 & 450 & \\
\hline & $1.5(1$ & $\theta H$ \\
\hline & 250 & $10(1)$ \\
\hline & $\because 00$ & 500 \\
\hline & $8(4)$ & \\
\hline & 2110 & 81 \\
\hline & $2(10)$ & \\
\hline & 200 & \\
\hline & 150 & e $0:$ \\
\hline & 59 & \\
\hline & 150 & \\
\hline & 1 ถึ) & \\
\hline & 100 & i) $\mathrm{nit}$ \\
\hline & 150 & \\
\hline & 2501 & 100 \\
\hline & $\because 00$ & \\
\hline & 250 & \\
\hline & $\because 001$ & 10 \\
\hline & 150 & \\
\hline & 250 & \\
\hline & 100 & \\
\hline & (6) & \\
\hline
\end{tabular}

Sorts, stocky, variegated leaved included.........................

Variegated leaved, $t$ sorts..

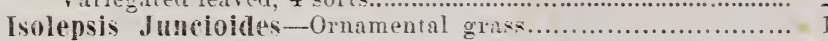

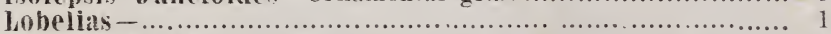

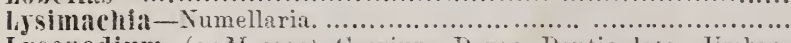

Lycopodium--(or Blusses). Caesium, Densa, Denticulata, Lmbrosum. Wilienovii

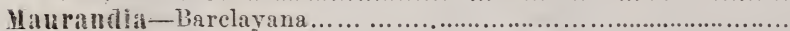

Pteris-Palmata......................................................

Russelia-Juncea ......................................................

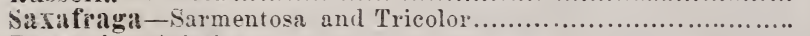

Torrenia-Asiatica.................................................

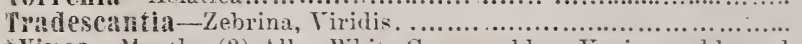

- Vinca-Uytle, (3) Alha. White Common blue, Tariegated leaved 20 , 2 (6) 8 (10

\section{ADDITIONA L TREF FREIGHT RATEG, \\ PER 100 POUNDS,}

Atchison, Kansas City, Leavenworth ani St. Josepis, 51.00; Darenport, Iowa, 8i) cunts; Denzer. \$3.60; Emporia, Kar.. \$1.58; Ft. Scott. \$1.40; Omaha, \$1.30; Salt Lake, Ttah, \$1.80; Topela, \$1.58; Boston, \$2.io); Buffalo and Pitsburgh, 31.10; Cincinati, 70 cents: Columbus and Dayton, 85 cents: Louisville, io cents; Tashville. Teun., \$1.40; Yerr York. \$1.90: Philadelphia ani Baltiucre, \$1.80; Toledo and Cleveland, it cears. 


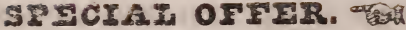

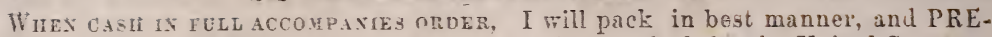
PAY ESPRESA CIIARGES to any Hailroad point reached by the United States or American Jerchants Union Express Company, in the States of Illinois, Wisconsin, Minnesota, Iowa, Hiscouri, Indiana. Ohio ani Michigan, as follows:

On packages of Plants, weight nor over $t$ pounis. for 50 cents additional.

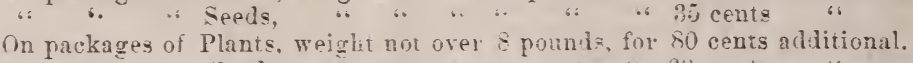

The above includes all charges for packing. As it is impossible to estimate the ExAcr weight of packages heforehand, be sure and send enough ; any overphu will be promptly returned.

\section{BOOKS AND COZORED PLATES.} Ordep Books for Canvassers-Best style.......................... 50 00 colored hithographs of Fruits-Drawn from nature................. 25

Flowers, Shrubs and Grapes...............

bes Fifty or more Colored Plates, in one orter. will be neatly and substantially houni, if desired, without extra charge. Senl for list. Fire samples of Colored Fruirs sent by mail for sil.

Plate Books, second-hand. for sale or rent by the season.

\section{PLANT YOUNG TREES.}

We advise most decidedly oplaut young trees. in orchard and gartens, hacause

1.-Foung trees cost less throughout-at the nuraery, in freight charges, alvo in bandling and planting.

2.-They are surer to grow, haring in proportion to the size of tops, vastly more and betker smalt, fine (fibrous) roots. Large trees in moving usually lose half or tnore of their most raluable roots.

3.- - Having less tops and almost pertect roots, the small trees become established, and grow of vigoronsiy at once. The tops of large trees newly planted are often shaken and blown about by the wind wil they become leaning, and unhealthy, eren if they survive.

4.-Making most of their growth on the ground where liey are to stand, the smali trees soon become more stocky and sturdy, every way perfectly adapted to the soil and location, as well as the preference of their owner. Setting young trees the planter can finshion both bodies and rops exactly to suit his fancy.

5.- "Setting such young trees will we not lose time?"' you ask. To answer :ruly, I reply, if you give these yonng trees the first year or two a littlo extra voatching and care, to the amount, say, of the ilfference in their cost, jou willsot lose a day, but get thereby a much handsomer and more valuable orchard.

t.-Or, if not realy to plant out in the orchard permanently this year-or, if about to open in a year or two a new farm as for a Son or Daughter, why not plant yearlings or root grafts growing them yourself in the garden with but tritling cost. In the mean time your children can stuly and learn all about them as well as about colts or pigs. Root Graftz are set in leep, mellow soil, with dirt firm about roots. dipped, just before setting, in "grout," $i$. e. mud and water, with the top of Grait or Cion. two inches or so abnte surface.

The most thorough and successiul large planters we cannot persuale to buy and plant ordinary or large-sized trees. Eren at the same price they invariably prefer the 1 or 2 year trees, knowing that with a fuir ehance the young, thrifty trees will, in 4 or 6 year's at most, nvertake the hest planted large trees. Planting a few large trees for immediate bearing aud effect, as about cities and $10 \mathrm{wns}$, is a very different matiex. In such saseo expense and risk are no object. Fut the distant dweller on the prairies has neithor money nor time to tamper with such large trees. Give bim the young trees, and with reasonabie care be can soon show better specimens than his more ambitious, suburban neighbor, beaides the money he sares by planting small trees. 